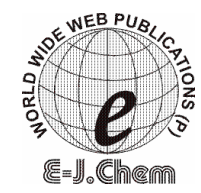

http://www.e-journals.net

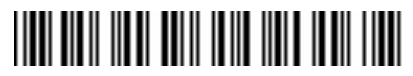

ISSN: 0973-4945; CODEN ECJHAO

E-Journal of Chemistry

Vol. 5, No. 1, pp. 120-129, January 2008

\title{
Microwave Assisted Improved Method for the Synthesis of Pyrazole Containing 2,4,-Disubstituted Oxazole-5-one and their Antimicrobial Activity
}

\author{
N. D. ARGADE, B. K. KALRALE and C. H. GILL* \\ P. G. Department of Chemistry, S.S.G.M. Collage, Kopergone, \\ Ahmednagar-423601, University of Pune, India (M.S). \\ *Department of Chemistry, Dr.B.A.Marathwada University, \\ Aurangabad - 431004. India, (M.S). \\ and_2002@rediffmail.com, Fax: +91796924504.
}

Received 5 June 2007; Accepted 20 July 2007

\begin{abstract}
Disubstituted oxazol-5-one and pyrazoles are known to exhibit various biological activities. Therefore, in this work, we designed pyrazole containing 2,4-disubstituted oxazol-5-one (3a-g) as a new class of antimicrobial agents. Synthesis of titled compounds was carried out by two different methods. In the first method (conventional Method A), disubstituted oxazol-5-one (3a-g) was prepared by reacting 1-phenyl-3-p-tolyl-1Hpyrazole-4-carbaldehyde (1a-g) with hippuric acid (2) and sodium acetate, in an acetic anhydride for 2.5 - $4 \mathrm{~h}$. In the second method (Method B), the above reaction was carried out under microwave assistance. Compared to the conventional method, the microwave-assisted synthesis of 3,4,5-trisubstituted imidazoles demonstrate several advantages, in terms of reaction time and overall yield. All the test compounds were evaluated for in vitro antibacterial and antifungal activities. In general, compounds with electron withdrawing groups showed good antibacterial and antifungal activities. Among the compound tested, compound (3d) showed highest activity.
\end{abstract}

Keywords: Microwave assisted synthesis, Hippuric acid, Substituted 4-oxazol-5-one's, Antimicrobial activity. 


\section{Introduction}

Heterocyclic compounds are acquiring more importance in recent years due to the pharmacological activities. Nitrogen, sulphur, oxygen, contanining five/six member heterocyclic compounds has occupied enormous significance in the field of drug discovery process. Substituted oxazole, pyrazole and their analogs have been used as precursors for synthesis of various biologically active molecules, oxazole derivatives as brain-derived neurotrophic factor inducers ${ }^{1}$, analgesic ${ }^{2}$, trypanocidal activity ${ }^{3}$, anti-mitotic agents with pro-apoptotic activity ${ }^{4}$, antifungal activity ${ }^{5}$, antiinflammatory ${ }^{6}$, anti-depressant ${ }^{7}$, anti-cancer ${ }^{8}$, ant-microbial, ant-diabetic and antiobesity ${ }^{9-10}$. Oxazolidinones have attracted attention as a new class of orally active synthetic antibiotics with a unique mechanism of bacterial protein synthesis inhibition ${ }^{11-14}$. Literature survey reveals that less attention is given to the synthesis of oxazole nucleus having pyrazol link. The oxazole with ether linkage at fifth position are found to possess good anti-bacterial, anti-inflammatory and CNS activity $^{15-16}$. Synthesis of substituted oxazole a different method is available in literature ${ }^{17}$, they have used different supported KF catalysts, and it is aldehyde dependent reaction.

It has been observed that the substituents have great influence on the formation of 2,4disubstituted oxazoles and also the reaction time and percent yield varies with the type of substituents. Therefore, none of the above methods were found to be versatile for the synthesis of pyrazole containing 2,4-disubstituted oxazoles. In the recent years, the efficiency of microwave chemistry in dramatically reducing reaction times has recently been proven in several different fields of organic chemistry ${ }^{18}$, microwave-assisted organic synthesis has shown significant improvement in the generation of combinatorial libraries of small molecules ${ }^{19}$. In general, microwave irradiation was found to be very useful to accelerate the rate of reaction of various thermally conducted reactions and also this technique was found to be very useful to improve an overall yield and reaction selectivity. Moreover, microwave chemistry assures safe and reproducible experimental procedures. Thus, in the present investigation, along with the conventional method, we decided to develop microwave-assisted one-pot facile method for the synthesis of pyrazoles containing 2,4-disubstituted oxazoles as a new class of antimicrobial agents.

\section{Experimental}

Melting points were determined in open capillary tubes and are uncorrected. IR spectra carried out on Perkin-Elmer FTIR spectrophotometer $\left(\mathrm{cm}^{-1}\right.$, in $\left.\mathrm{KBr}\right) .{ }^{1} \mathrm{H}$ NMR and ${ }^{13} \mathrm{C}$ NMR spectra were recorded on a Bruker spin spectrometer $(400 \mathrm{MHz})$ in DMSO- $d 6$ and TMS was used as internal standard. Peak values are shown in ppm, in the $\delta$ scale. Mass spectra were recorded on a Waters LC-MS. Elemental analyses were carried out on Perkin-Elmer analyzer. Starting materials were obtained from s.d.fine and Aldrich.

\section{Synthesis Protocol}

Synthesis of 1-(4- substituted-phenyl)- 3-(4- substituted-phenyl)- 1H-pyrazole- 4carbaldehyde (1a-g):

Syntheses of the 1-(4-substituted-phenyl)-3-(4-substituted-phenyl)-1H-pyrazole-4-carbaldehydes 1a-g were carried out using a literature procedure and their spectral data are given below.

\section{1-Phenyl-3-p-tolyl-1H-pyrazole-4-carbaldehyde (1a):}

$\mathrm{R}_{\mathrm{f}} 0.40$ (30\% EtOAc in hexane), IR $\left(\mathrm{cm}^{-1}\right): 1715 .{ }^{1} \mathrm{H}$ NMR (400 MHz, DMSO- $\left.d_{6} ; \delta \mathrm{ppm}\right): 9.95$ $(\mathrm{s}, 1 \mathrm{H}), 9.30(\mathrm{~s}, 1 \mathrm{H}), 7.99-8.01(\mathrm{~m}, 1 \mathrm{H}), 7.82-7.84(\mathrm{~m}, 2 \mathrm{H}), 7.55-7.61(\mathrm{~m}, 2 \mathrm{H}), 7.49-7.54(\mathrm{~m}$, 2H), 7.32-7.35 (m, 2H), 2.1 (s, 3H). MS (EI): 262(M+1). Anal. Calc. for $\mathrm{C}_{17} \mathrm{H}_{14} \mathrm{~N}_{2} \mathrm{O}: \mathrm{C}, 77.84$; H, 5.40; N, 10.67; O, 6.10. Found: C, 77.85; H, 5.40; N, 10.68; O, $6.11 \%$. 


\section{1,3-Diphenyl-4H-pyrazole-4-carbaldehyde (1b):}

$\mathrm{R}_{\mathrm{f}} 0.30$ (30\% EtOAc in hexane), IR $\left(\mathrm{cm}^{-1}\right): 1710 .{ }^{1} \mathrm{H}$ NMR (400 MHz, DMSO- $\left.d_{6} ; \delta \mathrm{ppm}\right)$ : $9.99(\mathrm{~s}, 1 \mathrm{H}), 9.34(\mathrm{~s}, 1 \mathrm{H}), 7.99-8.01(\mathrm{~m}, 2 \mathrm{H}), 7.92-7.94(\mathrm{~m}, 2 \mathrm{H}), 7.55-7.61(\mathrm{~m}, 2 \mathrm{H}), 7.49$ $7.54(\mathrm{~m}, 3 \mathrm{H}), 7.42-7.45(\mathrm{~m}, 1 \mathrm{H})$. MS (EI): $248(\mathrm{M}+1)$. Anal. Calc. for $\mathrm{C}_{16} \mathrm{H}_{12} \mathrm{~N}_{2} \mathrm{O}: \mathrm{C}, 77.40$; H, 4.87; N, 11.27; O, 6.44. Found: C, 77.41; H, 5.88; N, 11.28; O, $6.41 \%$.

\section{3-(4-Bromo-phenyl)-1-phenyl-1H-pyrazole-4-carbaldehyde (1c):}

$\mathrm{R}_{\mathrm{f}} 0.50$ (30\% EtOAc in hexane), IR $\left(\mathrm{cm}^{-1}\right): 1719 .{ }^{1} \mathrm{H}$ NMR $\left(400 \mathrm{MHz}\right.$, DMSO- $\left.d_{6} ; \delta \mathrm{ppm}\right)$ : $9.98(\mathrm{~s}, 1 \mathrm{H}), 9.32(\mathrm{~s}, 1 \mathrm{H}), 7.99-8.11(\mathrm{~m}, 2 \mathrm{H}), 7.92-7.94(\mathrm{~m}, 2 \mathrm{H}), 7.55-7.57(\mathrm{~m}, 2 \mathrm{H}), 7.49-7.54$ $(\mathrm{m}, 2 \mathrm{H}), 7.42-7.43(\mathrm{~m}, 1 \mathrm{H})$. MS (EI): 327(M+1). Anal. Calc. for $\mathrm{C}_{16} \mathrm{H}_{11} \mathrm{~N}_{2} \mathrm{OBr}: \mathrm{C}, 58.74 ; \mathrm{H}$, 3.37; N, 8.57; O, 4.88; Br, 24.42. Found: C, 58.71; H, 3.38; N, 8.58; O, 4.89; Br, $24.43 \%$.

\section{3-(4-Chloro-phenyl)-1-phenyl-1H-pyrazole-4-carbaldehyde (1d):}

$\mathrm{R}_{\mathrm{f}} 0.56$ (30\% EtOAc in hexane), IR $\left(\mathrm{cm}^{-1}\right): 1711 .{ }^{1} \mathrm{H}$ NMR (400 MHz, DMSO- $\left.d_{6} ; \delta \mathrm{ppm}\right)$ : $9.93(\mathrm{~s}, 1 \mathrm{H}), 9.36(\mathrm{~s}, 1 \mathrm{H}), 7.99-8.11(\mathrm{~m}, 2 \mathrm{H}), 7.92-7.94(\mathrm{~m}, 2 \mathrm{H}), 7.85-7.87(\mathrm{~m}, 2 \mathrm{H}), 7.49-7.54$ $(\mathrm{m}, 2 \mathrm{H}), 7.32-7.33(\mathrm{~m}, 1 \mathrm{H})$. MS (EI): 282(M+1). Anal. Calc. for $\mathrm{C}_{16} \mathrm{H}_{11} \mathrm{~N}_{2} \mathrm{OCl}: \mathrm{C}, 67.97 ; \mathrm{H}$, 3.92; N, 9.91; O, 5.66; Cl, 12.52. Found: C, 67.96; H, 3.93; N, 9.93; O, 5.65; Cl, $12.54 \%$.

\section{1-(4-Chloro-phenyl)-3-(4-nitro-phenyl)-1H-pyrazole-4-carbaldehyde (1e):}

$\mathrm{R}_{\mathrm{f}} 0.66$ (30\% EtOAc in hexane), IR $\left(\mathrm{cm}^{-1}\right): 1716,1555 .{ }^{1} \mathrm{H}$ NMR (400 MHz, DMSO- $d_{6}$; $\delta$ ppm): $9.98(\mathrm{~s}, 1 \mathrm{H}), 9.46(\mathrm{~s}, 1 \mathrm{H}), 7.99-8.11(\mathrm{~m}, 2 \mathrm{H}), 7.92-7.94(\mathrm{~m}, 2 \mathrm{H}), 7.85-7.87(\mathrm{~m}, 2 \mathrm{H})$, 7.66-7.69 (m, 2H). MS (EI): 329(M+1). Anal. Calc. for $\mathrm{C}_{16} \mathrm{H}_{10} \mathrm{~N}_{3} \mathrm{O} 3 \mathrm{Cl}$ : C, 58.27; H, 3.37; N, 12.71; O, 14.56; Cl, 10.75. Found: C, 58.26; H, 3.38; N, 12.71; O, 14.55; Cl, $10.74 \%$.

\section{1-(4-Chloro-phenyl)-3-phenyl-1H-pyrazole-4-carbaldehyde (1f):}

$\mathrm{R}_{\mathrm{f}} 0.56$ (30\% EtOAc in hexane), IR $\left(\mathrm{cm}^{-1}\right): 1716 .{ }^{1} \mathrm{H}$ NMR (400 MHz, DMSO- $\left.d_{6} ; \delta \mathrm{ppm}\right)$ : $9.96(\mathrm{~s}, 1 \mathrm{H}), 9.31(\mathrm{~s}, 1 \mathrm{H}), 7.95-8.98(\mathrm{~m}, 2 \mathrm{H}), 7.92-7.94(\mathrm{~m}, 2 \mathrm{H}), 7.85-7.87(\mathrm{~m}, 2 \mathrm{H}), 7.69-7.70$ $(\mathrm{m}, 2 \mathrm{H}), 7.34-7.36(\mathrm{~m}, 1 \mathrm{H})$. MS (EI): 282(M+1). Anal. Calc. for $\mathrm{C}_{16} \mathrm{H}_{11} \mathrm{~N}_{2} \mathrm{OCl}: \mathrm{C}, 67.97 ; \mathrm{H}$, 3.92; N, 9.93; O, 5.67; Cl, 12.52. Found: C, 67.99; H, 3.93; N, 9.93; O, 5.65; Cl, $12.50 \%$.

\section{3-(4-Methoxy-phenyl)-1-phenyl-1H-pyrazole-4-carbaldehyde (1g):}

$\mathrm{R}_{\mathrm{f}} 0.30$ (30\% EtOAc in hexane), IR $\left(\mathrm{cm}^{-1}\right): 1710 .{ }^{1} \mathrm{H}$ NMR (400 MHz, DMSO- $\left.d_{6} ; \delta \mathrm{ppm}\right)$ : $9.95(\mathrm{~s}, 1 \mathrm{H}), 9.38(\mathrm{~s}, 1 \mathrm{H}), 7.99-8.11(\mathrm{~m}, 1 \mathrm{H}), 7.83-7.85(\mathrm{~m}, 2 \mathrm{H}), 7.55-7.61(\mathrm{~m}, 3 \mathrm{H}), 7.54-$ $7.32(\mathrm{~m}, 3 \mathrm{H}), 3.1(\mathrm{~s}, 3 \mathrm{H})$. MS (EI): 278(M+1). Anal. Calc. for $\mathrm{C}_{17} \mathrm{H}_{14} \mathrm{~N}_{2} \mathrm{O}_{2}: \mathrm{C}, 73.37 ; \mathrm{H}$, 5.04; N, 10.07; O, 11.50. Found: C, 73.35; H, 5.08; N, 10.08; O, $11.51 \%$.

\section{Method A}

A mixture of Compound 1 (200mg, 0.763mmol), (127mg, 0.764mmol) of powdered dry hippuric acid (2), (125mg, 1.252mmol) of powdered freshly sodium acetate and (200mg, 2mmol) high grade acetic anhydride. The reaction mixture heated on oil bath $100{ }^{\circ} \mathrm{C}$ for $2.5-4 \mathrm{~h}$ with constant shaking. During this time a part of product separates as deep yellow crystals. Cooled reaction mixture, icecooled water $(15-20 \mathrm{~mL})$ was added, solid obtained which is filter and washed with more ice-cooled water, dry to $60{ }^{\circ} \mathrm{C}$ for $2 \mathrm{~h}$ under vacuum, to obtain the compounds $\mathbf{3}$ as yellow colored solid.

\section{Method B}

A mixture of Compound 1 (200mg, 0.763mmol), (127mg, 0.764mmol) of powdered dry hippuric acid (2), (125mg, 1.252 mmol) of powdered freshly sodium acetate and (200mg, 2mmol) high grade acetic anhydride. Reaction mixture was placed in the CEM Discover microwave and was irradiated at $150 \mathrm{~W}$ and $100{ }^{\circ} \mathrm{C}$ for 10 to 20 minutes. Mixture was cooled to $0{ }^{\circ} \mathrm{C}$ and poured over ice-cooled 
water $(20 \mathrm{~mL})$, precipitate obtained was filtered, washed with water $(2$ X $20 \mathrm{~mL})$, dry to $60{ }^{\circ} \mathrm{C}$ for $2 \mathrm{hr}$ under vacuum, to get the compounds $\mathbf{3}$ as pale yellow colored solid.

2-phenyl-4- (1-phenyl-3-p-tolyl-1H-pyrazol-4-ylmethylene)-4H-oxazol-5-one (3a):

$\mathrm{R}_{\mathrm{f}} 0.45$ (30\% EtOAc in hexane), IR $\left(\mathrm{cm}^{-1}\right): 1720 .{ }^{1} \mathrm{H}$ NMR (400 MHz, DMSO- $d_{6}$; $\delta \mathrm{ppm}): 9.38(\mathrm{~s}, 1 \mathrm{H}), 8.27-8.25(\mathrm{~m}, 2 \mathrm{H}), 8.06-8.04(\mathrm{~m}, 2 \mathrm{H}), 7.75-7.71(\mathrm{~m}, 1 \mathrm{H}), 7.67-$ $7.64(\mathrm{~m}, 3 \mathrm{H}), 7.63-7.62(\mathrm{~m}, 2 \mathrm{H}), 7.60-7.59(\mathrm{~m}, 1 \mathrm{H}), 7.48-7.46(\mathrm{~m}, 1 \mathrm{H}), 7.44-7.40(\mathrm{~m}$, $2 \mathrm{H}), 7.15(\mathrm{~m}, 1 \mathrm{H}), 2.42(\mathrm{~s}, 3 \mathrm{H})$. MS (EI): 405(M+1). Anal. Calc. for $\mathrm{C}_{26} \mathrm{H}_{19} \mathrm{~N}_{3} \mathrm{O}_{2}: \mathrm{C}$, 77.02; H, 4.74; N, 10.37; O, 7.90. Found: C, 77.75; H, 4.78; N, 10.38; O, $7.91 \%$.

4-(1,3-Diphenyl-1H-pyrazol-4-ylmethylene)-2-phenyl-4H-oxazol-5-one (3b):

$\mathrm{R}_{\mathrm{f}} 0.55$ (30\% EtOAc in hexane), IR $\left(\mathrm{cm}^{-1}\right): 1725$. ${ }^{1} \mathrm{H}$ NMR (400 MHz, DMSO- $d_{6}$; $\delta \mathrm{ppm}): 9.31(\mathrm{~s}, 1 \mathrm{H}), 8.27-8.24(\mathrm{~m}, 2 \mathrm{H}), 7.96-7.94(\mathrm{~m}, 2 \mathrm{H}), 7.75-7.71(\mathrm{~m}, 1 \mathrm{H}), 7.67-$ $7.64(\mathrm{~m}, 3 \mathrm{H}), 7.62-7.61(\mathrm{~m}, 2 \mathrm{H}), 7.56-7.54(\mathrm{~m}, 2 \mathrm{H}), 7.43-7.41(\mathrm{~m}, 1 \mathrm{H}), 7.34-7.30(\mathrm{~m}$, $2 \mathrm{H}), 7.05-7.02(\mathrm{~m}, 1 \mathrm{H})$. MS (EI): 391(M+1). Anal. Calc. for $\mathrm{C}_{25} \mathrm{H}_{17} \mathrm{~N}_{3} \mathrm{O}_{2}: \mathrm{C}, 76.72 ; \mathrm{H}$, 4.38; N, 10.73; O, 8.17. Found: C, 76.71; H, 4.38; N, 10.73; O, 8.19\%.

4-[3-(4-Bromo-phenyl)-1-phenyl-1H-pyrazol-4-ylmethylene]-2-phenyl-4H-oxazol-5-one (3c):

$\mathrm{R}_{\mathrm{f}} 0.45$ (30\% EtOAc in hexane), IR $\left(\mathrm{cm}^{-1}\right): 1720 .{ }^{1} \mathrm{H}$ NMR $\left(400 \mathrm{MHz}, \mathrm{DMSO}-d_{6} ; \delta \mathrm{ppm}\right)$ : $9.28(\mathrm{~s}, 1 \mathrm{H}), 8.37-8.35(\mathrm{~m}, 2 \mathrm{H}), 8.16-8.14(\mathrm{~m}, 2 \mathrm{H}), 7.75-7.71(\mathrm{~m}, 1 \mathrm{H}), 7.67-7.64(\mathrm{~m}, 3 \mathrm{H})$, 7.62-7.60 (m, 2H), 7.59-7.57 (m, 2H), 7.44-7.40 (m, 2H), 7.05-7.02 (m, 1H). MS (EI): 470(M+1). Anal. Calc. for $\mathrm{C}_{25} \mathrm{H}_{16} \mathrm{~N}_{3} \mathrm{O}_{2} \mathrm{Br}$ : C, 63.82; H, 3.44; N, 8.97; O, 6.80; Br, 16.99 Found: C, 63.85; H, 3.45; N, 8.98; O, 6.81; Br, $16.98 \%$.

4-[3-(4-Chloro-phenyl)-1-phenyl-1H-pyrazol-4-ylmethylene]-2-phenyl-4H-oxazol-5-one (3d):

$\mathrm{R}_{\mathrm{f}} 0.65$ (30\% EtOAc in hexane), IR $\left(\mathrm{cm}^{-1}\right): 1710 .{ }^{1} \mathrm{H}$ NMR (400 MHz, DMSO- $\left.d_{6} ; \delta \mathrm{ppm}\right)$ : $9.21(\mathrm{~s}, 1 \mathrm{H}), 8.32-8.30(\mathrm{~m}, 2 \mathrm{H}), 8.12-8.10(\mathrm{~m}, 2 \mathrm{H}), 7.77-7.73(\mathrm{~m}, 2 \mathrm{H}), 7.67-7.64(\mathrm{~m}, 2 \mathrm{H})$, 7.63-7.61 (m, 2H), 7.57-7.53 (m, 2H), 7.42-7.40 (m, 2H), 7.15-7.12 (m, 1H). MS (EI): 425(M+1). Anal. Calc. for $\mathrm{C}_{25} \mathrm{H}_{16} \mathrm{~N}_{3} \mathrm{O}_{2} \mathrm{Cl}: \mathrm{C}, 70.52 ; \mathrm{H}, 3.79 ; \mathrm{N}, 9.87 ; \mathrm{O}, 7.50 ; \mathrm{Cl}, 8.32$ Found: C, 70.55; H, 3.78; N, 9.88; O, 7.51; Cl, 8.33\%.

4-[1-(4-Chloro-phenyl)-3-(4-nitro-phenyl)-1H-pyrazol-4-ylmethylene]-2-phenyl4H-oxazol-5-one $\mathbf{( 3 e )}$ :

$\mathrm{R}_{\mathrm{f}} 0.35$ (30\% EtOAc in hexane), IR $\left(\mathrm{cm}^{-1}\right): 1720 .{ }^{1} \mathrm{H}$ NMR $\left(400 \mathrm{MHz}, \mathrm{DMSO}-d_{6} ; \delta \mathrm{ppm}\right)$ : $9.41(\mathrm{~s}, 1 \mathrm{H}), 8.42-8.40(\mathrm{~m}, 2 \mathrm{H}), 8.32-8.30(\mathrm{~m}, 2 \mathrm{H}), 7.87-7.83(\mathrm{~m}, 2 \mathrm{H}), 7.77-7.74(\mathrm{~m}, 2 \mathrm{H})$, 7.68-7.66 (m, 1H), 7.57-7.53 (m, 2H), 7.52-7.50 (m, 2H), 7.35-7.32 (m, 1H). MS (EI): 472(M+1). Anal. Calc. for $\mathrm{C}_{25} \mathrm{H}_{15} \mathrm{~N}_{4} \mathrm{O}_{4} \mathrm{Cl}: \mathrm{C}, 63.50 ; \mathrm{H}, 3.62 ; \mathrm{N}, 11.87 ; \mathrm{O}, 13.50 ; \mathrm{Cl}, 7.52$ Found: C, 63.55; H, 3.65; N, 11.88; O, 13.51; Cl, $7.53 \%$.

4-[1-(4-Chloro-phenyl)-3-phenyl-1H-pyrazol-4-ylmethylene]-2-phenyl-4H-oxazol-5-one (3f):

$\mathrm{R}_{\mathrm{f}} 0.55$ (30\% EtOAc in hexane), IR $\left(\mathrm{cm}^{-1}\right): 1725 .{ }^{1} \mathrm{H}$ NMR $\left(400 \mathrm{MHz}, \mathrm{DMSO}-d_{6} ; \delta \mathrm{ppm}\right)$ : $9.11(\mathrm{~s}, 1 \mathrm{H}), 8.32-8.30(\mathrm{~m}, 2 \mathrm{H}), 8.22-8.20(\mathrm{~m}, 2 \mathrm{H}), 7.97-7.93(\mathrm{~m}, 2 \mathrm{H}), 7.87-7.84(\mathrm{~m}, 2 \mathrm{H})$, 7.78-7.76 (m, 1H), 7.67-7.63 (m, 2H), 7.58-7.55 (m, 2H), 7.53-7.30 (m, 2H). MS (EI): 425(M+1). Anal. Calc. for $\mathrm{C}_{25} \mathrm{H}_{16} \mathrm{~N}_{3} \mathrm{O}_{2} \mathrm{Cl}: \mathrm{C}, 70.50 ; \mathrm{H}, 3.79 ; \mathrm{N}, 9.87 ; \mathrm{O}, 7.50 ; \mathrm{Cl}, 8.32$ Found: C, 70.52; H, 3.79; N, 9.88; O, 7.51; Cl, $8.33 \%$.

4-[3-(4-Methoxy-phenyl)-1-phenyl-1H-pyrazol-4-ylmethylene]-2-phenyl-4H-oxazol-5-one (3g):

$\mathrm{R}_{\mathrm{f}} 0.45$ (30\% EtOAc in hexane), IR $\left(\mathrm{cm}^{-1}\right): 1720 .{ }^{1} \mathrm{H}$ NMR $\left(400 \mathrm{MHz}\right.$, DMSO- $\left.d_{6} ; \delta \mathrm{ppm}\right)$ : $8.91(\mathrm{~s}, 1 \mathrm{H}), 8.22-8.20(\mathrm{~m}, 2 \mathrm{H}), 8.12-8.10(\mathrm{~m}, 2 \mathrm{H}), 7.77-7.73(\mathrm{~m}, 2 \mathrm{H}), 7.67-7.64(\mathrm{~m}, 2 \mathrm{H})$, 7.63-7.62 (m, 1H), 7.60-7.58 (m, 2H), 7.54-7.52 (m, 2H), 7.50-7.49 (m, 2H), 3.2 (s, 3H). 
MS (EI): 421(M+1). Anal. Calc. for $\mathrm{C}_{26} \mathrm{H}_{19} \mathrm{~N}_{3} \mathrm{O}_{3}: \mathrm{C}, 74.10 ; \mathrm{H}, 4.54 ; \mathrm{N}, 9.97 ; \mathrm{O}, 11.39$. Found: C, 74.12; H, 4.55; N, 9.98; O, $11.41 \%$.

Using Method A and B, total seven derivatives of compounds 3a-g were prepared. The spectral data of compounds 3a-g, obtained by Method A and B were found to be identical and are listed below.

\section{Procedure for the determination of the antibacterial activity}

The in vitro antibacterial activities of test compounds were evaluated by cup-plate method, using standard literature protocol ${ }^{20}$. Nutrient agar was melted on a water bath and cooled to $45^{\circ} \mathrm{C}$ with gentle shaking to bring about uniform cooling. It was inoculated with $0.5-0.6 \mathrm{~mL}$ of culture and mixed by gentle shaking before pouring onto a sterilized Petri dish. The poured material was allowed to set and 4-cups were then made by punching the agar surface with a sterile cork bore $(5 \mathrm{~mm})$ and the punched part of the agar media was removed by scooping. Solutions containing 15, 20, 25 and $30 \mu \mathrm{g} / \mathrm{mL}$ of the test compound were added to each cup. Dimethyl sulfoxide (DMSO; $1 \%$ ) was used as a solvent to prepare the stock solution of the test compounds. The drug was allowed to diffuse for about $4 \mathrm{~h}$ into the agar medium before adding the suspension of the test bacteria. The tests were carried out in duplicate. Apart from running controls of standard drugs (Streptomycin, Ampicillin), controls with DMSO (positive control) and without DMSO (negative control) were also included in the test. The plates were incubated at $37{ }^{\circ} \mathrm{C}$ for $48 \mathrm{~h}$ and the results were recorded. The zones of inhibition of the microbial growth $(100 \mu \mathrm{g} / \mathrm{disc})$ produced by different concentration of test compounds were measured in millimeters ( $\mathrm{mm}$ ).

\section{Procedure for the determination of the antifungal activity}

The in vitro antifungal activity of test compounds was evaluated using Candida albicans (ATCC 10231) strain, by the test tube dilution technique, in Saboraud's dextrose broth culture media. The stock solution of test compounds were prepared in a mixture of sterile water and DMSO (1\%) and the serial dilution of test compounds were carried out to obtain the corresponding concentration, ranging from 15, 30, 45 and 60 $\mu \mathrm{g} / \mathrm{mL}$. The test compounds at various concentrations were added to culture medium in a sterilized borosilicate tube and the fungal strain was inoculated at $5 \times 10^{15} \mathrm{CFU} / \mathrm{mL}$. The tubes were incubated at $37{ }^{\circ} \mathrm{C}$ for $48 \mathrm{~h}$ and visually examined for the presence or absence of growth of the test organisms. All the experiments were performed in duplicate. Apart from running controls of standard drugs (Fluconazole Ketaconazole and Clotrimazole), controls with DMSO (positive control) and without DMSO (negative control) were also included in the test.

\section{Results and Discussion}

In this work, total seven derivatives of pyrazoles containing 2,4-disubstituted oxazoles (3a-g) were prepared either by using base-induced cycloaddition of hippuric acid (2) to $1 \mathrm{H}$ pyrazole-4-carbaldehyde in an solvent such as acetic anhydride or using microwave assisted one- pot synthesis (Scheme 1). In the first method (Method A), 1-(4-substituted-phenyl)-3(4-substituted-phenyl)-1H-pyrazole-4-carbaldehyde (1a-g) was in turn obtained by Vilsmeier reaction on acetophenone hydrazones, hyppuric acid (2), acetic anhydride and sodium acetate. In second method (Method B), title compound was carried out by microwave-assisted synthesis, using compound (1a-g), hyppuric acid (2), acetic anhydride and sodium acetate. 
<smiles>[R]c1ccc(-c2nn(-c3ccc([R])cc3)cc2C=O)cc1</smiles>

1<smiles>CC(=O)OCC(C)C(C)=O</smiles>

2<smiles>[R]c1ccc(-c2nn(-c3ccc([R])cc3)cc2/C=C2\N=C(c3ccccc3)OC2=O)cc1</smiles>

\section{Scheme 1}

All the titled compounds 3a-g and their intermediates 1a-g were characterized by their analytical and spectral data. The IR spectra $\left(\mathrm{cm}^{-1}\right)$ of compound $\mathbf{1}$ showed characteristic absorption band in the range of $1690-1720$ due to $\mathrm{C}=\mathrm{O}$ stretching of carbaldehyde. The IR spectra of compound 3 showed disappearance of band in the region of $1690-1720$ due to $\mathrm{C}=\mathrm{O}$ stretching and appearance of band in the region of 1710-1730 due to $\mathrm{O}=\mathrm{C}-\mathrm{O}$ (lactone $\mathrm{C}=\mathrm{O}$ ) stretching. The ${ }^{1} \mathrm{H}$ NMR spectra of compound 1 showed characteristic peaks $(\delta \mathrm{ppm})$, in the range of 9.80-9.95 due to $1 H$ proton of carbaldehyde. Compound 3 showed peaks in the region of 8.25-8.29 due to the methylene proton and 7.46-5.79 due to one more phenyl ring respectively. The ESI-MS showed characteristic molecular ion peaks, which corresponds with the molecular weight of the synthesized compounds. The CHN analyses were found within the limit of \pm 0.04 of calculated values, which confirmed the formation of titled compounds. All the physicochemical properties of intermediates and titled compounds are given in the experimental section.

As shown in Table 1, when the synthesis of compounds 3a-g were attempted using a conventional method (Method A), it took 2.5 $-4 \mathrm{~h}$ for the completion of reaction and the overall yield were found in the range of 50-75\%. When the same reaction was attempted using the onepot microwave-assisted synthesis, reaction was successfully completed within 10-20 minutes and the overall yields were found in the range of 80-92 \%. Using Method B, attempts were also made to carry out reaction, within 3-5 minutes, however it mainly resulted into incomplete reaction and also the overall yield were found in the range of 30-40 \%. Similarly, using Method B we attempted to prepare the titled compounds 3a-g, by conducting reaction over a long period (30-60 $\mathrm{min})$. This mainly resulted into the formation of degraded product. Thus microwave-assisted synthesis of compounds 3a-g were found to be time specific and compare to conventional method, it led to the formation of title compounds in short time and the overall yield was found to be much higher than the conventional route of synthesis.

Table 1. Comparison of conventional versus microwave-assisted synthesis of 2,4disubstituted oxazoles (3a-g).

\begin{tabular}{llllllrlrc}
\hline S.No & Compounds & $\mathrm{R}$ & $\mathrm{R} 1$ & \multicolumn{3}{c}{ Method A } & \multicolumn{2}{c}{ Method B } \\
\cline { 5 - 8 } & & & & $\begin{array}{l}\text { M.P. } \\
0{ }^{0} \mathrm{C}\end{array}$ & $\begin{array}{l}\text { Time } \\
\text { min. }\end{array}$ & $\begin{array}{l}\text { Yield } \\
\%\end{array}$ & $\begin{array}{l}\text { Time } \\
\text { min. }\end{array}$ & $\begin{array}{l}\text { Yield } \\
\%\end{array}$ \\
\hline 1 & $3 \mathrm{a}$ & $\mathrm{CH}_{3}$ & $\mathrm{H}$ & 180 & 180 & 57 & 20 & 90 \\
2 & $3 \mathrm{~b}$ & $\mathrm{H}$ & $\mathrm{H}$ & 254 & 200 & 75 & 20 & 81 \\
3 & $3 \mathrm{c}$ & $\mathrm{Br}$ & $\mathrm{H}$ & 165 & 150 & 50 & 10 & 72 \\
4 & $3 \mathrm{~d}$ & $\mathrm{Cl}$ & $\mathrm{H}$ & 173 & 240 & 60 & 15 & 73 \\
5 & $3 \mathrm{e}$ & $\mathrm{NO}_{2}$ & $\mathrm{Cl}$ & 210 & 200 & 52 & 20 & 82 \\
6 & $3 \mathrm{f}$ & $\mathrm{H}$ & $\mathrm{Cl}$ & 154 & 150 & 60 & 18 & 89 \\
7 & $3 \mathrm{~g}$ & $\mathrm{OCH}_{3}$ & $\mathrm{H}$ & 167 & 210 & 75 & 22 & 92 \\
\hline
\end{tabular}


Antibacterial activity of test compounds 3a-g was determined using three different strains Staphylococcus aureus (Gram positive), Escherichia Coli (Gram negative) and Pseudomonas aeruginosa (Gram negative), by cup-plate method and the antifungal activity was evaluated using Candida albicans (ATCC 10231) strain, by broth dilution method. ${ }^{17}$ Stock solutions of test compounds were prepared in dimethyl sulfoxide (1\%) solution and antibacterial activity was carried out at four different concentrations $(15,20,25$ and 30 $\mu \mathrm{g} / \mathrm{mL})$. The antifungal activity was determined at four different concentrations $(15,30,45$ and $60 \mu \mathrm{g} / \mathrm{mL}$ ). Antibacterial activity of test compounds were compared with two different standard compounds (Ampicillin and Streptomycin, at 10 and $25 \mu \mathrm{g} / \mathrm{mL}$ concentrations) and the antifungal activity were compared with three different standards (Fluconazole Ketaconazole and Clotrimazole at 10, 20 and $30 \mu \mathrm{g} / \mathrm{mL}$ concentrations), while with and without DMSO (1\%) solution were used as positive and negative controls. The antimicrobial activity has been shown in Table 2, wherein, the antibacterial activity is represent as zone of inhibition $(\mathrm{mm})$ and the antifungal activity is represented in terms of gradation as excellent, good, poor and no growth, based upon visual observation.

Table 2. Antimicrobial activity of compounds 3a-g.

\begin{tabular}{|c|c|c|c|c|c|c|}
\hline \multirow[b]{2}{*}{ No. } & \multirow[b]{2}{*}{ Compd } & \multirow{2}{*}{$\begin{array}{c}\text { Conc. } \\
\mu \mathrm{g}\end{array}$} & \multicolumn{3}{|c|}{ Antibacterial (zone of inhibition mm) } & \multirow{2}{*}{$\begin{array}{c}\text { Antifungal } \\
\text { Candida albicans } \\
\text { (ATCC 10231) }\end{array}$} \\
\hline & & & E. coli & $\begin{array}{c}\text { Pseudomonas } \\
\text { aeruginosa }\end{array}$ & $\begin{array}{c}\text { Staphylococcus } \\
\text { aureus }\end{array}$ & \\
\hline \multirow[t]{6}{*}{1.} & 3a & 15 & - & - & - & -- \\
\hline & & 20 & - & - & - & NA \\
\hline & & 25 & 7.2 & 7. 0 & 7.2 & NA \\
\hline & & 30 & 7. 0 & 7. 1 & 8. 0 & -- \\
\hline & & 45 & NA & NA & NA & + \\
\hline & & 60 & NA & NA & NA & ++ \\
\hline \multirow[t]{6}{*}{2.} & 3b & 15 & - & - & - & -- \\
\hline & & 20 & - & - & - & NA \\
\hline & & 25 & - & - & - & NA \\
\hline & & 30 & - & - & - & -- \\
\hline & & 45 & NA & NA & NA & + \\
\hline & & 60 & NA & NA & NA & ++ \\
\hline \multirow[t]{6}{*}{3.} & $3 c$ & 15 & - & - & - & -- \\
\hline & & 20 & - & - & - & NA \\
\hline & & 25 & 6.1 & 6.2 & - & NA \\
\hline & & 30 & 6.4 & 7.1 & 8.2 & -- \\
\hline & & 45 & NA & NA & NA & + \\
\hline & & 60 & NA & NA & NA & + \\
\hline \multirow[t]{6}{*}{4.} & $3 d$ & 15 & - & - & - & -- \\
\hline & & 20 & - & - & - & NA \\
\hline & & 25 & 9.4 & 7.4 & 8.3 & NA \\
\hline & & 30 & 13.7 & 8.5 & 10.6 & -- \\
\hline & & 45 & NA & NA & NA & +++ \\
\hline & & 60 & NA & NA & NA & +++ \\
\hline
\end{tabular}




\begin{tabular}{|c|c|c|c|c|c|c|}
\hline \multirow[t]{6}{*}{5.} & $3 e$ & 15 & - & - & - & -- \\
\hline & & 20 & - & - & - & NA \\
\hline & & 25 & 7.4 & 6.1 & 6.2 & NA \\
\hline & & 30 & 11.7 & 7.2 & 8.6 & -- \\
\hline & & 45 & NA & NA & NA & + \\
\hline & & 60 & NA & NA & NA & + \\
\hline \multirow[t]{6}{*}{6.} & 3f & 15 & - & - & - & -- \\
\hline & & 20 & - & - & - & NA \\
\hline & & 25 & - & - & - & NA \\
\hline & & 30 & 6.0 & 6.2 & 6.8 & -- \\
\hline & & 45 & NA & NA & NA & + \\
\hline & & 60 & NA & NA & NA & + \\
\hline \multirow[t]{10}{*}{7.} & $3 g$ & 15 & - & - & - & -- \\
\hline & & 20 & - & - & - & NA \\
\hline & & 25 & - & - & - & NA \\
\hline & & 30 & - & - & - & -- \\
\hline & & 45 & NA & NA & NA & -- \\
\hline & & 60 & NA & NA & NA & + \\
\hline & $\mathbf{A}$ & 10 & 10 & - & 8 & -- \\
\hline & & 25 & 18 & 8 & 13 & NA \\
\hline & B & 10 & 18 & 6 & 8 & NA \\
\hline & & 25 & 20 & 18 & 9 & NA \\
\hline \multirow{9}{*}{ 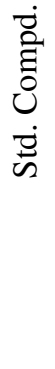 } & $\mathbf{C}$ & 10 & NA & NA & NA & -- \\
\hline & & 20 & NA & NA & NA & ++ \\
\hline & & 30 & NA & NA & NA & ++ \\
\hline & D & 10 & NA & NA & NA & -- \\
\hline & & 20 & NA & NA & NA & + \\
\hline & & 30 & NA & NA & NA & +++ \\
\hline & $\mathbf{E}$ & 10 & NA & NA & NA & ++ \\
\hline & & 20 & NA & NA & NA & +++ \\
\hline & & 30 & NA & NA & NA & +++ \\
\hline
\end{tabular}

Antibacterial activities were determined in three different strains and represented as zone of inhibition (mm). Antifungal activities were determined in a single strain,

Wherein '-' represent no inhibition; '+++' represent no growth; '++' represent poor growth; '+' represent moderate growth and '--' represent excellent growth. NA represents activity not determined.

Std. Compds used for antibacterial activity comparison are A: Ampicillin and B: Streptomycin. Std. Compds used for antifungal activity comparison are C: Ketaconazole; D: Fluconazole and E: Clotrimazole.

As shown in Table 2, with respect to the standard compounds, all the test compounds were found to be inactive at 15 and $20 \mu \mathrm{g} / \mathrm{mL}$ concentrations, against both the gramnegative strains and a gram-positive strain. Compound $\mathbf{3 a}$, at $30 \mu \mathrm{g} / \mathrm{mL}$ concentrations showed moderate antibacterial activity against both the gram negative and gram-positive strains. Compounds $\mathbf{3 b}, \mathbf{3 f}$ and $\mathbf{3 g}$ were found to be inactive even at higher concentrations $(25$ and $30 \mu \mathrm{g} / \mathrm{mL}$ ). Compounds $\mathbf{3 c}, \mathbf{3 d}$ and $\mathbf{3 e}$ showed good activity at 25 and $30 \mu \mathrm{g} / \mathrm{mL}$ concentrations. In general, compounds with electron withdrawing groups at ' $\mathbf{R}$ ' position 
were found to be very active among the series. Among all the compounds tested, compound 3d was found to be very active compound, in all the three different strains and at $30 \mu \mathrm{g} / \mathrm{mL}$ concentrations, antibacterial activity of compound $\mathbf{3 d}$ was found to be comparable with that of standard compounds, tested at 10 and $20 \mu \mathrm{g} / \mathrm{mL}$ concentrations.

Along with the antibacterial activity, all the test compounds showed antifungal activity at higher concentrations (45 and $60 \mu \mathrm{g} / \mathrm{mL}$ ). In general, compounds with electron withdrawing groups at ' $\mathbf{R}$ ' position were found to be very active among the series. Among all the compounds tested, compound $\mathbf{3 d}$ showed highest antifungal activity and its activity was found to be comparable with that of standard compounds tested. Combined evaluation of antimicrobial study results indicated that the new class of 2,4-disubstituted oxazole, which we designed acts as a broad-spectrum antibacterial and antifungal agent. Although the with respect to standard compounds, all the test compounds were found to be less potent but results of our preliminary study clearly indicated that the pyrazole containing 2,4disubstituted oxazole ring system represents a new class of pharmacophore for the broad spectrum antimicrobial activity. Further studies related to the lead optimization and mechanistic studies to understand the exact mode of action of this new class of compounds are in progress and will be published elsewhere.

\section{Acknowledgements}

Authors are thankful to Dr. Vivek N. Upasani, Department of Microbiology, M. G. Science Institute, University of Gujarat, India, for carrying out in vitro antimicrobial activity. We are also thankful to the National Chemical Laboratory (N.C.L.), Pune (India) for providing facility and literature assistance.

\section{References}

1. Maekawa T, Sakai N, Tawada H, Murase K, Hazama M, Sugiyama Y and Momose Y, Che. Pharm Bull (Tokyo), 2003, 51(5), 565-73.

2. Lesieur and Aichaw H, EUR PAT, 390, 673, Chem Abstr, 1991, 114, 143.

3. Sao Paulo, J Braz Chem Soc, 2001, 12, 3.

4. Uckun F M, Current Pharmaceutical Design, 2001, 7, 16, 1627-1639.

5. Kunes J, Balsanek V, Pour M and Buchta V, Czechoslovak Chemical Communications Abstracts, 2001, 66(12), 1809-1830.

6. Ando K and Asai N, EUR PAT, 385, 664, Chem Abstr, 1991, 114, 143.

7. Descas P and Jarry C, EUR PAT, 392, 929, Chem Abstr, 1991, 114, 143.

8. Benedlt D and Daniel V, J Med Chem, 1994, 37, 710.

9. Pereira E R, Sancelme M, Voldorie A and Prudhomme M, Bio-org, Med Chem Lit, 1997, 7(190), 2503.

10. Viti G, Namnicine R, Ricci R, Pestelline V, Abeli L and Funo M, Eur J Med Chem, 1994, 29, 401.

11. Cohen M L, Nature, 2000, 406, 762.

12. Brickner S J, Curr Pharm Design, 1996, 2, 175.

13. (a). Barbachyn M R, Brickner S J, Cleek G J, Gadwood R C, Grega K C, Hendges S K, Hutchinson D K, Manninen P R, Munesada K, Thomas R C, Thomasco L M, Toops D S and Ulanowicz D A, In Antiinfectives Recent advances in Chemistry and Structure Activity Relationships, P H Bentley, O'Hanlon, Ed., The Royal Society of Chemistry, Hartnolls Limited Bodmin, Cornwall, 1997, pp 15-26. (b). Barbachyn M R, Brickner S J, Gadwood R C, Garmon S A, Grega K C, Hutchinson D K, 
Munesada K, Reischer R J, Taniguchi M, Thomasco L M, Toops D S, Yamada H, Ford C W and Zurenko G E, In Resolving the Antibiotics Paradox, Rosen B P, Mobashery S, Ed., Kluwer Academic Plenum Publishers, New York, 1998, pp 219-240.

14. Shinabarger D A, Exp Opin Invest Drugs, 1999, 8, 1195. Chem Abstr 1999, 131, 269-300.

15. Desai N C, Dave D, Shah M D, Vyas G D, Indian J Chem, 2002, 348, 277.

16. Aglawe M J, Dhule S S, Bahekar S S, Wakte, P S and Shinde D B, J Korean Chem. Soc, 2003, 47, 02.

17. Felipa M, Bantista, Juan M, Campelo, Angel Garcia, Diego Luna, Jose M, Marinas Antonio A and Romero, J Chem Soc, 2002, 2, 227-234.

18. Olofson R A and Kendall R V, J Org Chem, 1970, 35, 2246.

19. Lidström P, Tierney J, Wathey B and Westman J, Tetrahedron, 2001, 57, 9225.

20. Chuickshank R, Dugid J P, Marmon D P and Swain R H, A. In Medical Microbiology, 1975, 2. (Churchill-livingstone, Edinburgh, Londone). 


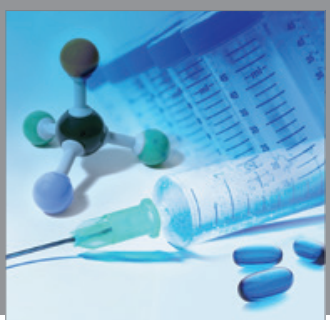

International Journal of

Medicinal Chemistry

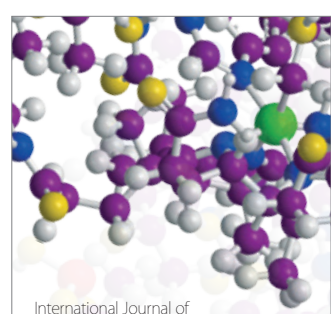

Carbohydrate Chemistry

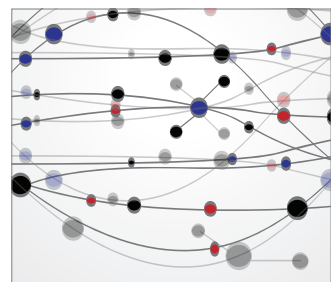

The Scientific World Journal
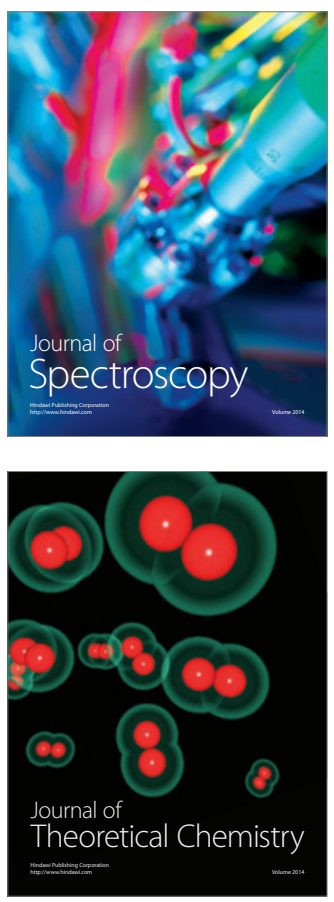
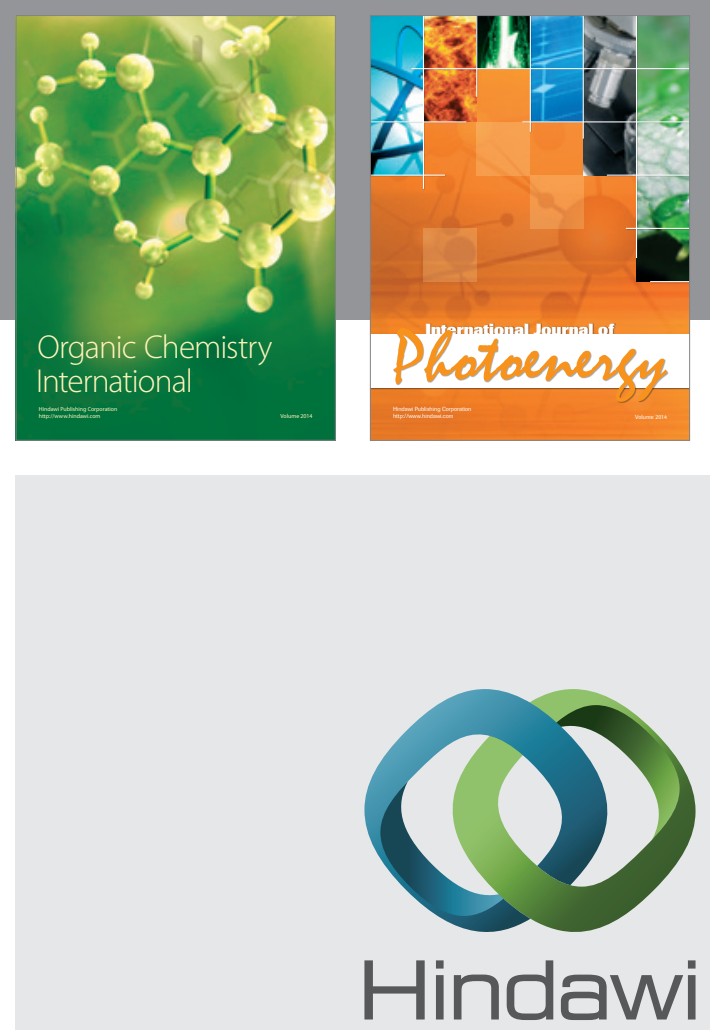

Submit your manuscripts at

http://www.hindawi.com
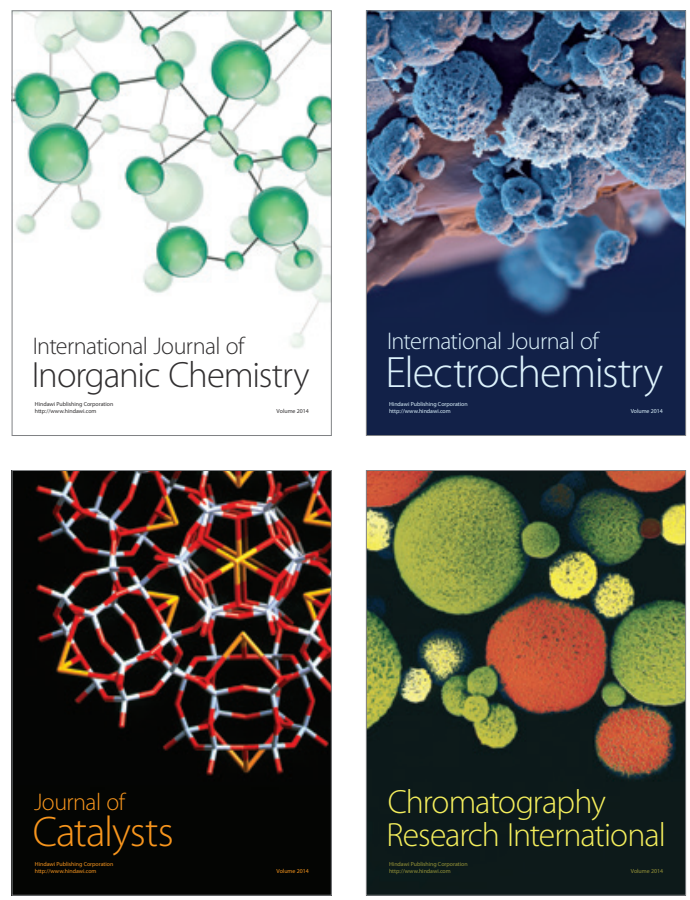
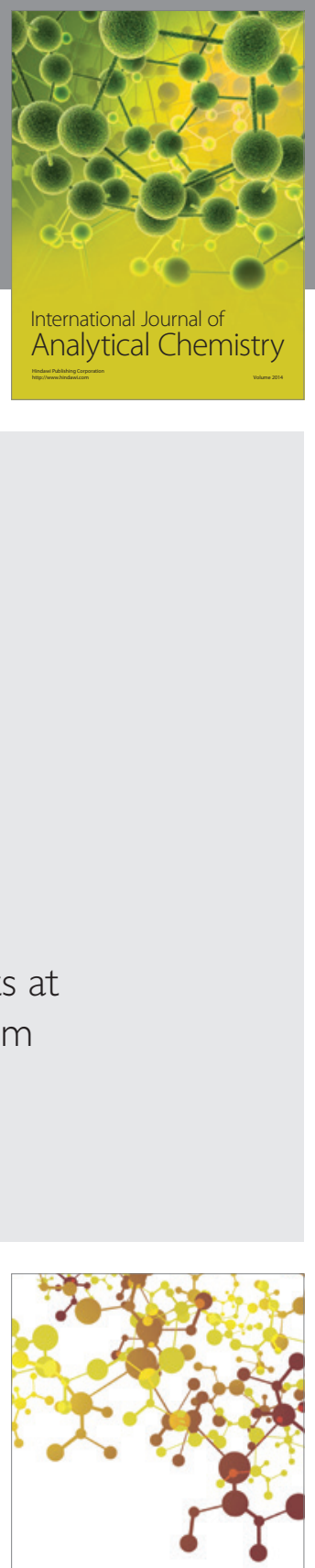

Journal of

Applied Chemistry
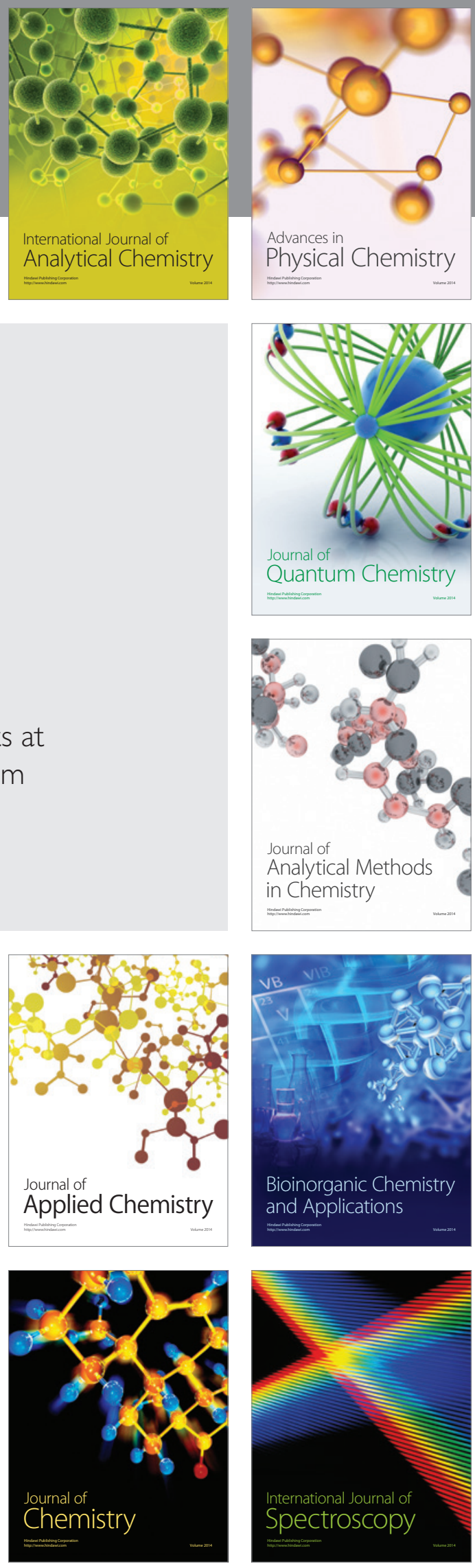